down the lacuna and false trails transformed into evidence for a Celtic mythology, showing they lead instead to a mythology about the Celts) is itself, of course, a fantasy, a myth. So, to those who would tell stories, and present new myths, the final contributor, Diane Purkiss, warns: 'it's more important to be wary and even ironic about the strategies available when none are foolproof'. Let the imagination fly, she suggests, we need all the stories we can get, but don't pretend that the string to the past can be completely cut free.

\section{Marsha Rowe}

\section{A Matter of Honour: Experiences of Turkish Women Immigrants}

\section{Tahire Kocturk}

Zed Books Ltd: London and New Jersey 1992, ISBN $1856490750 £ 29.95 \mathrm{Hbk}$; ISBN $1856490769 £ 11.95 \mathrm{Pbk}$

Tahire Kocturk explains that her book is the result of an attempt to make the voices of immigrant Turkish women living in Western Europe heard in the face of 'wellmeaning generalizations' and 'less friendly prejudices' - in other words, racism.

Muslim communities, like many other communities living in Western European societies, face individual and institutional racism. This book comes out at a time when fascist attacks on immigrants and refugees are on the increase and Western governments are facilitating further attacks by preparing the legislative ground. While refugee camps and the homes of Turkish immigrants are set on fire by fascists in Germany, the Young Conservatives of Britain distribute stickers on the Continent bearing slogans such as 'No Drugs, Islam and Turkey in the EEC'.

Kocturk's book arose out of a study she conducted between 1986 and 1989 on 'Family and gender relations among Muslim immigrants in Sweden'. She conducted interviews in the Stockholm and Upsala regions of Sweden, a country not necessarily typical of Western Europe. The information in the study is interesting and as implied by its title it is about a very specific section of immigrant women. She interviewed 49 women and 10 men and the interviewees are 'Turkish speaking adults from Anatolia with at least one marriage or engagement experience'. Single women, for instance, are not included in the survey. It is, therefore, arguable how representative her sample study is of the 'experiences of Turkish women immigrants' as suggested in the title of the book.

Out of 130 pages, only 30 are devoted to the description and analysis of the study; the remaining 100 contain historical background information. Historical documents, however, as described below are very much male-oriented and need to be re-studied from a woman's perspective. The scope of her historical account is also too wide and her analysis is flawed by generalizations.

The issues of immigrant women with Middle Eastern and Muslim backgrounds are quite difficult to discuss and such discussions are 'often ideologically charged' (Keddie, 1991). Anyone who wishes to discuss these issues will soon realise that while there are widespread prejudices that need to be overcome the problems of Muslim women should not be ignored.

The book provides interesting information on Islam and the honour ethic. Kocturk points out that many 'Islamic' customs, such as veiling and seclusion, pre-date Islam in the Mediterranean and the Middle East. As in other areas, Islam generally follows the Judaeo-Christian tradition. All three religions profess that man is superior to woman. 
The honour ethic as it applies to women's sexuality is not unique to Islam, but exists in most Mediterranean societies, Muslim and Christian alike, where there is the same idea of the centrality of a man's honour. This honour concerns the sexuality of all women in the extended family. 'Even when people distance themselves from formal religiosity, the honour ethic persists'.

The effect of the advent of Islam on the position of women is controversial. There is evidence to suggest that Islam initially brought improvements to the status of women on the Arabian Peninsula in the seventh century. In certain societies, however, women suffered a reduction in freedom under Islam. This was the case for Turkish women.

Describing the prohibitions to which Turkish women were subjected after the advent of Islam, Kocturk asks the following questions: 'How did women feel? Did they yearn for more freedom? Did they accept their situation with resignation or take it for granted without question? Did they ever wish to rebel?' She then points out, 'It is, unfortunately, difficult to find documents which reveal how Turkish women felt during this period.' Indeed, this is the major problem in writing such a book. Pointing out that it is only with historical perspective that cultural differences can be satisfactorily explained, Kocturk devotes the first chapter to the different periods of Turkish history in order to provide an understanding of the status of women. The book gives a substantial amount of historical background information.

But providing a historical perspective is in itself a difficult task, since, as Kocturk points out, 'history generally tells the story of men. Accounts about women are few, if not impossible to find. In the case of Turkey it is very difficult to find anything directly said or done by ordinary women.' Although she says she does not 'consider this a great hinderance as women can learn much about themselves by studying their men', it does pose a problem which the book fails to resolve.

The most interesting part of the book is the last chapter in which the immigrant women relate their experiences of such matters as the breakdown of the traditional extended family structure, marriage patterns, women's employment and its effect on the 'family honour', changing attitudes between generations, and domestic violence and divorce.

In her historical account, Kocturk looks at Turkish society in general and Turkish women in particular,'regardless of any similarities with Armenian, Assyrian and Kurdish people that may or may not exist'.

As a result of the assimilationist policies of successive Turkish governments, the identity of the Kurds has been denied in Turkey. She has been unable to differentiate between peoples of different ethnic background which results in serious mistakes in her observations and interpretations. For instance, she states that 'Official figures are difficult to find but it is estimated that there are about 60,000 Turks in the UK, of which about two-thirds are Cypriots', while there is no mention of the large Kurdish population living in Britain.

Although containing interesting background information, the book is quite eclectic and suffers from three major flaws: firstly the case study is limited to a small sample of women living in Sweden and does not reflect the experiences of Turkish immigrant women in general as the title suggests; secondly, her historical account does not provide an in-depth study and analysis of the existing written sources and historical documents from women's perspective; thirdly, the book does not help challenge the prejudices that Turkish people may have towards the Kurdish people, on 
the contrary, it perpetuates them by its generalizations.

\section{Tijen Ǔ̆uriş}

\section{A Life's Mosaic: The Autobiography of Phyllis Ntantala}

David Phillip: Cape Town 1992;

University of California Press: Berkeley 1993, ISBN 0 52008171 $4 £ 17.00 \mathrm{Hbk}$; ISBN $0520081722 £ 9.00 \mathrm{Pbk}$

The Mayibuye Centre for History and Culture in South Africa has been established at the University of the Western Cape specifically to document the struggle against apartheid. A Life's Mosaic is the latest addition to the series of books published by this centre, following in the wake of such titles as Women under Apartheid: In Photographs and Text. In South Africa feminism, although gathering momentum, is very much in its embryonic stage and women are rarely accorded a public say. For this reason alone it is laudable that the Mayibuye Centre makes a point of including women's experiences of apartheid in their publications. It is, furthermore, important that this book has been published in South Africa as well as abroad. Hopefully, it will play a consciousness-raising role in South Africa similar to Ellen Kuzwayo's autobiography Call $\mathrm{Me}$ Woman. A Life's Mosaic will also be an eye-opener to non-South African readers, because it dispels many of the prejudices and stereotypes Western women still tend to have vis-à-vis their African sisters: Phyllis Ntantala is neither uneducated nor downtrodden.

Ntantala's autobiography resembles Kuzwayo's in many respects. Both women were born into a traditional African family which

\section{Reference}

1 KEDDIE, Nicky (1991) 'Introduction' in Keddie, Nicky and Baron, Beth (1991) editors, Women in Middle Eastern History, Shifting Boundaries in Sex and Gender New Haven and London: Yale University Press. belonged to the landed gentry. In both books this early period of the women's lives is portrayed in idyllic terms. Ntantala (born 7 January 1920) stresses the central role her parents performed in the community and strikingly portrays the wealth of traditions and customs which formed the basis of her happy early childhood in Idutywa in the Transkei. Her dreamworld was shattered when she was four years old, when her mother died. Her mother's replacement by an unsympathetic and uncaring stepmother denotes the first of many episodes in her life which separate her from her traditional roots.

Her father's role is a curious one from a non-African perspective. She obviously feels a close bond with her father. She still refers to him in the traditional way as 'tata' (Xhosa for Daddy), and he did most of the dayto-day caring for his daughters after their mother's death. However, he did not make any effort to persuade his second wife, Edwina, to pay more attention to the children. Traditionally, the children were the woman's realm and officially he did not know of their neglect, so that he could not openly tell his wife to do more. Even the children themselves abided by this golden rule and never openly complained about Edwina to their father. This was taken to such extremes that when the stepmother's children started arriving, Ntantala and her sisters looked after them, rather than let their father know of their predicament. Yet Ntantala's father took a great interest in her education and from an early age impressed upon her that she was just 